\title{
Identifikasi penyebab penyakit busuk bulir bakteri pada tanaman padi (Oryza sativa) dan pengendaliannya menggunakan isolat Bacillus spp. secara in vitro
}

\author{
Identification of bacterial grain rot pathogen in rice (Oryza sativa) and its control \\ using Bacillus spp. isolates in vitro
}

\author{
Siti Juli Isnaeni ${ }^{1}$ dan Rachmi Masnilah2 $2^{*}$ \\ ${ }_{1}$ Program Studi Agroteknologi, Fakultas Pertanian, Universitas Jember, Indonesia \\ ${ }_{2}$ Program Studi Proteksi Tanaman, Fakultas Pertanian, Universitas Jember, Indonesia
}

\section{INFORMASI ARTIKEL}

\author{
*Korespondensi: \\ Rachmi Masnilah \\ rachmimasnilah@gmail.com \\ Informasi proses: \\ Received: 04 November 2019 \\ Accepted: 27 Desember 2019 \\ Published: 15 Januari 2020 \\ Cara sitasi:
} Isnaeni SJ and Masnilah R. (2020). Identifikasi penyebab penyakit busuk bulir bakteri pada tanaman padi (Oryza sativa) dan pengendaliannya menggunakan isolat Bacillus spp. secara in vitro. Jurnal Proteksi Tanaman Tropis 1(1): 14-20

DOI: $10.19184 /$ jptt.v1i1.15584

\begin{abstract}
Bacterial grain rot disease in rice plants is a new disease in Indonesia. The disease can reduce rice production by up to $40 \%$ in severe disease attacks. Morphological and physiological identification of these pathogens can be useful as a strategy of disease control. Control of this disease using Biological Control Agent is the right step and eco-friendly. The research was conducted in July until November 2018 at Plant Quarantine Laboratory of Agricultural Quarantine Center Surabaya. The design of the experiment used on pathogenic identification is descriptively and analytically while in the strategy of disease control used are Randomized Complete Design method of single factor as many as five treatment of Bacillus spp. such as; Ba1: Bacillus spp. isolate 1, Ba2: Bacillus spp. isolate 2, Ba3: Bacillus spp. isolate 3, Ba4: Bacillus spp. isolate 4, and Ba5: Bacillus isolate spp. 5. Research results showed that the pathogen causing bacterial grain rot in Rice is Burkholderia glumae with bacterial characteristics are Gram-negative, aerobic, not fluorescent on Kings $\mathrm{B}$ medium, mesophyll, isotonic, can hydrolysis arginine and can produce enzyme of gelatinase and (2) Bacillus spp. Isolate which consistent to inhibiting $B$. glumae in vitro is Ba-1 with a mean inhibition of $17.88 \mathrm{~mm}$ and a variety of resistance mechanisms, namely bacteriostatic and bactericidal isolate of Bacillus spp.
\end{abstract}

Keywords: Bacterial grain rot rice; Bacillus spp; Burkholderia glumae

\section{Pendahuluan}

Tanaman padi merupakan tanaman yang dianggap penting karena hasil panen berupa beras dapat memenuhi kebutuhan makanan masyarakat di Indonesia. Berdasarkan Kementerian Pertanian RI (2014), menyatakan bahwa kegiatan impor terhadap beras mencapai $2.989 .070 .425 \mathrm{~kg}$ atau sebanyak 2.989.070 ton yang dimulai pada bulan Januari Tahun 2014 - Bulan September Tahun 2017. Hal tersebut menunjukkan bahwa hasil produksi dalam negeri tidak seimbang dengan kebutuhan masyarakat. Terjadinya penurunan nilai produksi dapat dipengaruhi oleh faktor biotik dan abiotik.

Menurut Nandakumar et al. (2009), faktor abiotik seperti anomali iklim dan cuaca dapat memungkinkan terjadinya pengaruh oleh faktor biotik seperti peningkatan intensitas penularan penyakit. Penyakit yang baru-baru ini muncul pada tanaman padi setelah ada pada tahun 1995 dan 1998 disebabkan adanya serangan penyakit busuk bulir (grain rot) oleh bakteri Burkholderia glumae. Bakteri B. glumae termasuk patogen terbawa benih padi dimana memberikan 
dampak pertumbuhan tanaman menjadi tidak normal dan hasil kualitas gabah menurun.

Menurut Lu et al. (2014), bahwa penyakit busuk bulir disebabkan oleh bakteri B. glumae dapat menurunkan kehilangan hasil produksi mencapai $40 \%$ sehingga merugikan petani. $B$. glumae dapat menyebabkan tanaman padi terserang penyakit busuk bulir (grain rot), busuk pelepah (sheath rot), dan busuk bibit (seedling rot) (Nandakumar et al. 2009). Morfologi B. glumae yaitu struktur sel yang berbentuk batang agak melengkung dengan ukuran 0,5-0,7 × 1,5-2,5 $\mu \mathrm{m}$ dan memiliki flagella polar multitrichous. Bakteri dapat tumbuh optimal pada suhu berkisar antara $30-35^{\circ} \mathrm{C}$ (Schaad et al. 2001).

Upaya pengendalian terhadap penyakit ini dapat dilakukan dengan menghindari suhu tinggi di awal musim tanam, penggunaan varietas tahan, dan pemanfaatan agen pengendali hayati (APH). Menurut Prihatiningsih et al. (2015), mekanisme yang dimiliki oleh setiap APH meliputi: (1) antibiosis, (2) kompetisi, (3) mikoparasitisme, (4) enzim pendegradasi dinding sel, dan (5) ketahanan terimbas atau terinduksi.

Mekanisme yang dimiliki oleh bakteri dari genus Bacillus adalah antibiosis. Sifat antagonis pada bakteri Bacillus spp. adalah mampu menekan pertumbuhan mikroorganisme lain karena memproduksi antibiotik berupa lipopeptida yang disebut basitrasin dengan mekanisme merusak membran sel bakteri dan menghambat senyawa bakteri lainnya. Antibiotik ini akan menghambat aktivitas pertumbuhan serta metabolisme dari mikroorganisme lainnya yang memiliki kosentrasi lebih rendah. Jenis metabolit sekunder sebagai antibiotik yang diproduksi Bacillus spp. adalah bio-surfaktan yang disebut surfaktin atau subtilisin (Putra dan Giyanto 2014). Struktur endospora pada Bacillus spp. membuatnya memiliki eksistensi yang tinggi di alam karena spora tersebut tahan terhadap cekaman lingkungan.

\section{Metode penelitian}

\section{Metode percobaan.}

Penelitian dilakukan secara deskriptif yaitu pengamatan morfologi dan fisiologis serta secara analitik yaitu menggunakan Rancangan Acak Lengkap (RAL) faktor tunggal dengan perlakuan (Ba1) dengan isolat Bacillus spp. 1, (Ba2) dengan isolat Bacillus spp. 2, (Ba3) dengan isolat Bacillus spp. 3, (Ba4) dengan isolat Bacillus spp. 4, (Ba5) dengan isolat Bacillus spp. 5 yang diulang sebanyak 4 kali. Data dianalisis dengan sidik ragam dan apabila terdapat perlakuan berbeda nyata dilanjutkan dengan menggunakan uji Duncan's Multiple Range Test (DMRT) pada taraf 5\%.

\section{Pengambilan Sampel.}

Sampel bulir sakit didapatkan dari koleksi Laboratorium Karantina Tumbuhan Balai Besar Karantina Pertanian (BBKP) Surabaya yang sebelumnya telah dilakukan pengujian secara laboratoris dan memiliki hasil positif mengandung bakteri penyebab penyakit busuk bulir tanaman padi. Sampel bakteri antagonis yang digunakan adalah bakteri Bacillus spp. dengan kode isolat $\mathrm{Ba} 1$ dan $\mathrm{Ba} 2$ berasal dari koleksi isolat Tesha Virga Rana dari Fakultas Pertanian, Program Studi Agroteknologi. Isolat bakteri Bacillus spp. dengan kode Ba3, Ba4, dan Ba5 berasal dari koleksi Balai Besar Perbenihan dan Proteksi Tanaman Perkebunan (BBPPTP) Kabupaten Jombang.

\section{Peremajaan Isolat Bakteri Bacillus spp.}

Isolat bakteri Bacillus spp. yang diperoleh kemudian diremajakan dengan memindahkan bakteri dari kultur stok dengan teknik gores menggunakan jarum ose steril ke media YPGA secara kuadran sehingga mendapatkan koloni tunggal. Setelah didapatkan koloni tunggal lalu dilakukan pengujian KOH 3\% dan Pewarnaan Gram.

\section{Isolasi Patogen Busuk Bulir Bakteri.}

Menimbang bulir sakit sebanyak $10 \mathrm{~g}$ dan ditumbuk kasar lalu ditambahkan $10 \mathrm{ml}$ air steril kemudian inkubasi 2 jam pada suhu ruangan. Suspensi sebanyak $1 \mathrm{ml}$ di campurkan ke dalam $9 \mathrm{ml}$ larutan fisiologis $0,8 \%$ lalu dihomogenkan dan melakukan pengenceran bertingkat $10^{-7}$. Sebanyak $50 \mu \mathrm{l}$ suspensi disemprotkan pada media agar SPG dan diratakan dengan beadts steril. Inkubasi selama 48 jam dalam kondisi petri tertutup plastik wrap dan petri terbalik pada suhu $33^{\circ} \mathrm{C}$. Koloni bakteri yang sesuai selanjutnya dimurnikan pada media SPG dan Kings B.

\section{Uji Fisiologis Bakteri.}

Pengujian fisiologis bakteri penyebab penyakit busuk bulir padi meliputi: uji $\mathrm{KOH} 3 \%$, pewarnaan Gram, O/F, pertumbuhan pada media YDC, D1M, pH 4 dan 8 , suhu $40^{\circ} \mathrm{C}, \mathrm{NaCl} 3 \%$, hidrolisis arginin, gelatin, pati, hipersensitif, dan patogenesitas. Hasil-hasil pengujian fisiologis dibandingkan dengan karakteristik B. glumae menurut Schaad et al. (2001).

\section{Uji Antagonis Bacillus spp. Terhadap B. glumae}

Bakteri Bacillus spp. ditumbuhkan pada cawan petri berisi media YPGA) sebanyak 1 (satu) isolat per cawan petri yang dilakukan dengan perendaman kertas borer pada $10 \mathrm{ml}$ suspensi Bacillus spp. kemudian diinkubasi selama 48 jam pada suhu ruangan. Selanjutnya, cawan Petri dibalik dan beri larutan kloroform $1 \mathrm{ml}$ dari bagian tepi tutup petri lalu biarkan selama 2 jam. Cawan Petri dibalik ke posisi semula. Suspensi bakteri patogen $(0,2 \mathrm{ml}$ suspensi air steril bakteri patogen dalam $4 \mathrm{ml} 0,6 \%$ agar air pada suhu $45^{\circ} \mathrm{C}$ ), dituang pada permukaan medium tersebut lalu 
diinkubasi selama 24 jam pada suhu ruang. Terbentuk berupa zona hambatan diukur sesuai zona bening (Saputra et al. 2015). Pengukuran dilakukan dengan rumus (Izza et al. 2018):

$$
D P=\frac{D H+D V}{2}
$$

Ket.: $\mathrm{DP}=$ Daya Hambat $(\mathrm{mm}) ; \mathrm{DH}=$ Diameter zona bening Bacillus spp. secara horizontal; DV= Diameter zona bening Bacillus spp. secara vertikal

\section{Uji Mekanisme Hambatan}

Zona bening pada media agar uji antagonis diambil secara aseptis serta dihancurkan dengan scalpel steril kemudian dimasukkan dalam tabung reaksi berisi $1 \%$ air pepton. Vorteks media sampai homogen lalu digojok menggunakan shaker $120 \mathrm{rpm}$ selama $1 \times 24$ jam sampai $5 \times 24$ jam pada suhu ruang. Air pepton yang tidak keruh terus di gojok sampai 5 hari, jika tetap bening maka menunjukkan mekanisme penghambatan bersifat bakteriostatik dan jika berubah keruh menunjukkan mekanisme bakteriosidal (Arwiyanto 1997).

\section{Variabel Pengamatan}

Variabel pengamatan dalam penelitian ini yaitu: Pengamatan meliputi gejala, hasil isolasi, morfologi, pengamatan karakteristik sifat fisiologi bakteri sesuai dengan Schaad et al. (2001), patogenesitas, daya hambat, dan mekanisme hambatan.

\section{Hasil Penelitian}

Gejala busuk bulir bakteri padi dapat ditunjukkan dengan adanya gejala busuk bewarna kuning kecoklatan yang umumnya di mulai dari bagian pangkal ke ujung bulir disertai garis horizontal. Selain itu, gejala busuk dapat berupa bitnik kecil yang menyebar tidak merata pada bagian bulir padi (Gambar $1)$.

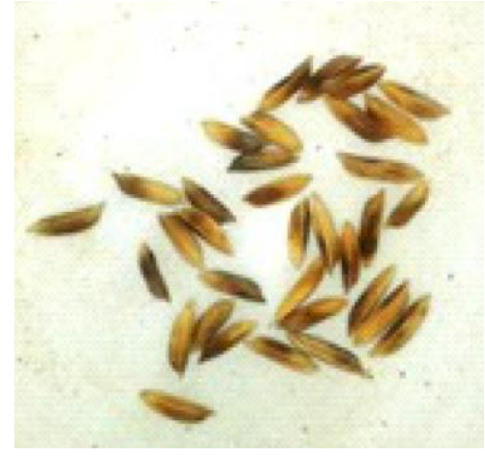

Gambar 1. Gejala penyakit busuk bulir padi

Hasil isolasi pemurnian patogen busuk bulir padi pada media SPG terdapat beberapa bakteri yang diberik kode isolat: Bg-1, Bg-2, Bg-3, Bg-4, dan Bg-5.
Koloni bakteri Bg-1 sampai Bg-5 (Gambar 2) menunjukkan pertumbuhan koloni bewarna ungu pada media SPG dan berlendir.
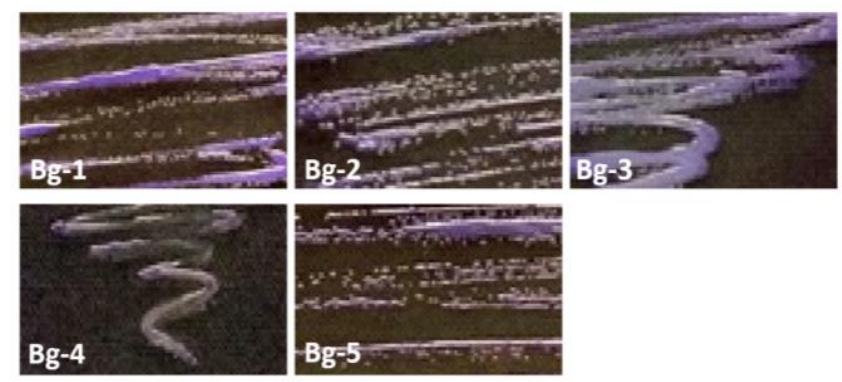

Gambar 2. Hasil isolasi bakteri setelah dimurnikan di media SPG

Hasil isolasi pada media SPG menunjukkan ciri koloni berbentuk bulat dengan warna kuning bening dibagian tepi dan warna ungu di bagian tengah koloni (Gambar 3A) dan jika di streak pada media SPG menghasilkan koloni berlendir bewarna ungu pekat (Gambar 3B). Pada media Kings B, koloni bakteri bewarna kuning kehijauan (Gambar 3C). Koloni dilihat dan diukur diameternya menggunakan mikroskop kompon 1.000×. berbentuk bulat konveks dengan elevasi cembung dan berdiameter 868,70 $\mu \mathrm{m}$ (Gambar 3D).

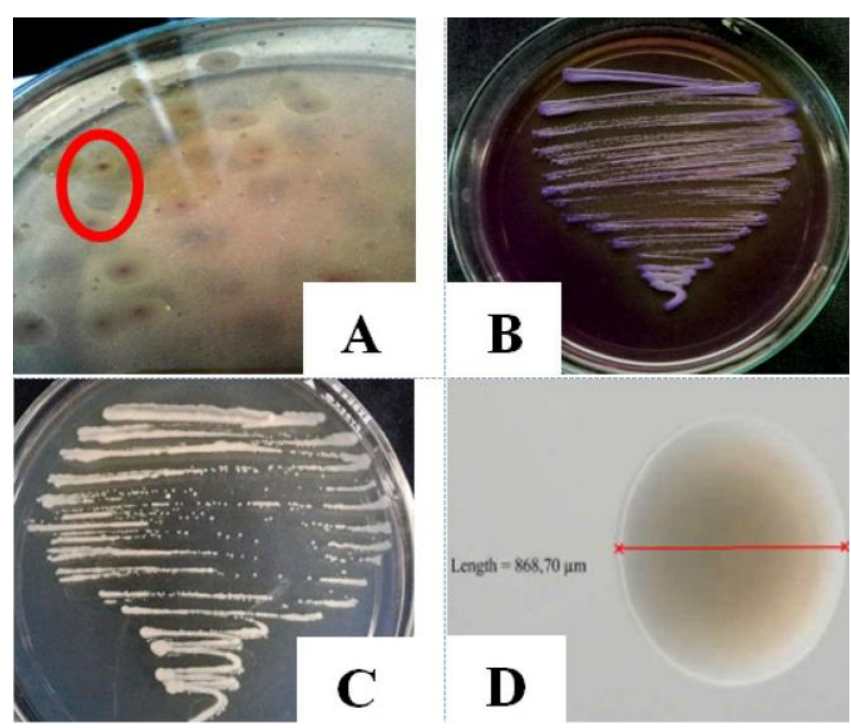

Gambar 3. Hasil isolasi (A) Metode spread plate pada media SPG, (B) Isolat Bg-2 metode streak pada media SPG, (C) Pada media Kings B, dan (D) Koloni tunggal Bg2.

\section{Identifikasi Penyebab Penyakit Busuk Bulir Bakteri pada Tanaman Padi}

Isolat Bg-2 di media Kings B tidak berpendar di sinar UV $(\lambda=366 \mathrm{~nm})$. Uji pewarnaan Gram menghasilkan sel bewarna merah, berbentuk batang dengan ukuran panjang 2,14 $\mu \mathrm{m}$ dan lebar 0,63 $\mu \mathrm{m}$ ). Isolat Bg-1 s.d. Bg-5 merupakan bakteri Gram negatif, 
bersifat oksidatif pada media $\mathrm{O} / \mathrm{F}$, dan koloni bewarna putih di media YDC. Pertumbuhan lambat di media D1M dihasilkan oleh Bg-3, Bg-2, dan Bg-5 di hari ke-5 inkubasi, sedangkan Bg-1 dan Bg-4 memiliki pertumbuhannya yang sangat lambat pada hari ke-7 inkubasi (Gambar 4).
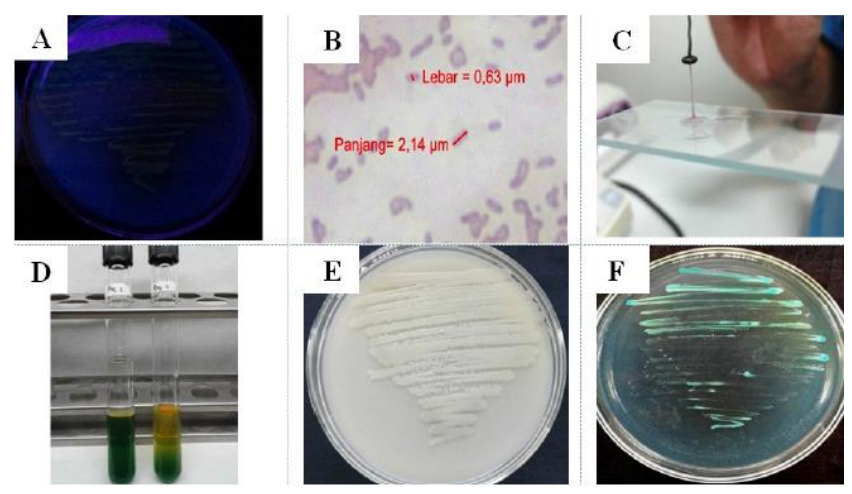

Gambar 4. Hasil pengujian fisiologis Bg-2 (A) Media Kings B dilihat menggunakan sinar UV, (B) Pewarnaan Gram, (C) Uji KOH 3\%, (D) Uji Oksidatif (kanan) Fermentatif (kiri), (E) Pertumbuhan pada media YCD, dan (F) Pertumbuhan pada media D1M.

Berdasarkan hasil pengujian fisiologis pertumbuhan isolat Bg-1 sampai Bg-5 pada $\mathrm{pH} 4$ dan $\mathrm{pH} 8$ (Gambar 1), isolat yang sesuai dengan Schaad et al. (2001) adalah Bg-2. Hal tersebut dapat dilihat Bg-2 bereaksi negatif pada pengujian fisiologis $\mathrm{pH} 4$ dimana media tidak berubah menjadi keruh (Gambar 5A) dan bereaksi V pada pH 8 dimana media berubah menjadi keruh (Gambar 5B). Hasil pengujian fisiologi Bg-1 sampai Bg5 (Tabel 1) menunjukkan isolat mampu tumbuh pada media NBY cair dengan suhu $40^{\circ} \mathrm{C}$ maupun media yang diberi perlakuan penambahan $3 \% \mathrm{NaCl}$. Hal tersebut dilihat dari perubahan media menjadi keruh.
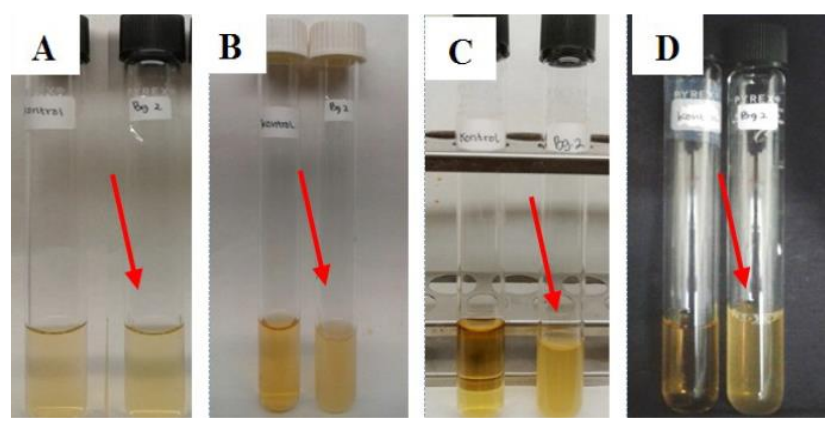

Gambar 5. Hasil pengujian fisiologis B. glumae (A) Uji pH 4, (B) Uji pH 8, (C) Uji suhu $40^{\circ} \mathrm{C}$, dan (D) Uji di $3 \% \mathrm{NaCl}$.

Berdasarkan uji fisiologis hidrolisis arginin bereaksi positif ditunjukkan dengan perubahan warna media menjadi magenta (Gambar 6A). Pada uji hidrolisis gelatin (Gambar 6B) bereaksi positif ditunjukkan dengan perubahan media menjadi cair. Pada uji hidrolisi pati bereaksi negatif dimana terjadinya perubahan warna media pati setelah diberi larutan iodin yakni menjadi biru (Tabel 1; Gambar 6C). Berdasarkan hasil uji hipersensitif
(HR) daun tembakau bereaksi positif berupa gejala nekrose ditandai dengan adanya bercak kuning kecoklatan di bagian daun yang terinokulasi patogen (Gambar 6D). Gejala muncul hari ke 2 masa inokulasi dan mengalami layu di bagian daun tembakau terjadi pada hari ke 5 masa inokulasi.
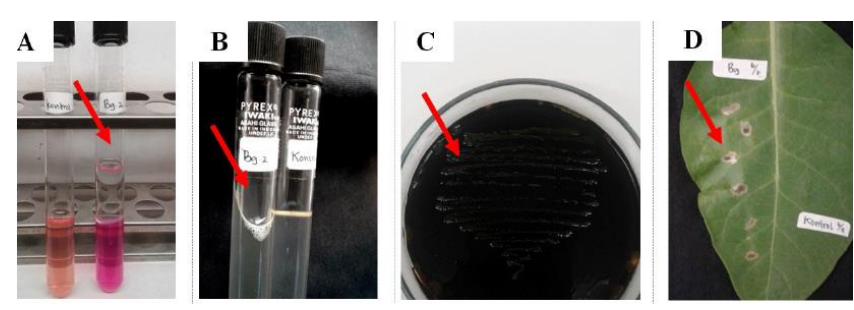

Gambar 6. Hasil Pengujian fisiologis $\mathrm{Bg}-2$ (A) Uji dihirolisis arginin, (B) Uji Hidrolisis gelatin, (C) Uji hidrolisis pati, dan (D) Uji Hipersensitif pada daun Tembakau.

Hasil uji patogenesitas (Gambar 7) pada tanaman padi berumur 45 hari setelah semai bereaksi positif. Bagian pelepah ditunjukkan adanya gejala busuk bewarna merah kecoklatan yang membentang secara horizontal. Bagian daun ditunjukkan adanya bercak kemerahan di tepi daun yang dikelilingi warna kuning seperti hawar pada daun.
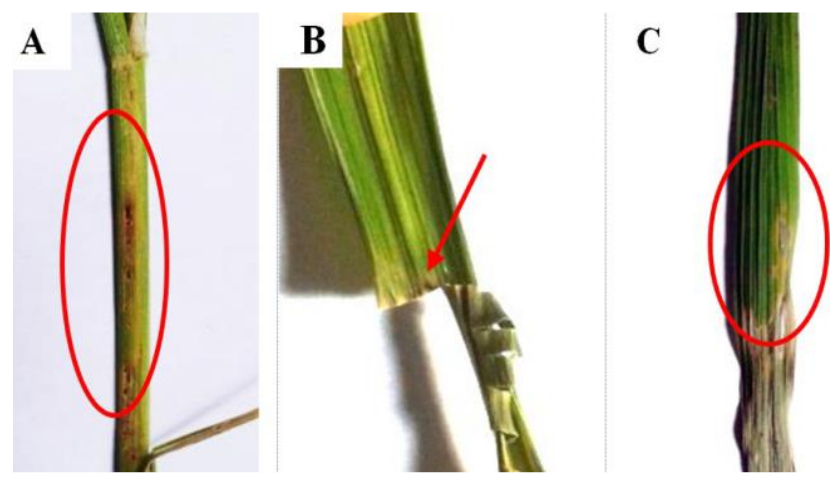

Gambar 7. Hasil uji patogenesitas isolat B. glumae pada tanaman padi (A) Bagian pelepah dan (B, C) Bagian daun.

Berdasarkan karakter morfologi, hasil uji fisiologi, dan patogenesitas menunjukkan bahwa penyebab penyakit busuk bulir padi adalah bakteri Burkholderia glumae (Tabel 1).

\section{Daya Hambat Bacillus spp. terhadap Penyebab Penyakit Busuk Bulir pada Tanaman Padi}

Hasil menunjukkan bahwa bakteri Bacillus spp. berpotensi menghambat $B$. glumae secara in vitro yang ditunjukkan dengan adanya daya hambat berupa zona bening disekitar isolat Bacillus spp. Tidak semua isolat konsisten menghambat pada setiap satuan percobaan kecuali Ba-1 (Gambar 8). 
Tabel 1. Hasil karakteristik secara fisiologis isolat penyebab busuk bulir bakteri pada padi

\begin{tabular}{lcccccc}
\hline Jenis Pengujian & \multicolumn{5}{c}{ Hasil Uji } \\
\cline { 2 - 6 } & Bg-1 & Bg-2 & Bg-3 & Bg-4 & Bg-5 & Schaad \\
\hline Gram (KOH 3\%) & - & - & - & - & - & - \\
Oksidatif & + & + & + & + & + & + \\
Berpendar di media KB & - & - & - & - & - & - \\
Pertumbuhan di media & - & - & - & - & - & - \\
YDC & & & & & & \\
Pertumbuhan di media & - & V & + & - & V & - \\
D1M & & & & & & \\
Pertumbuhan pada pH 4 & + & - & + & - & + & - \\
Pertumbuhan pada pH 8 & - & V & - & - & + & V \\
Pertumbuhan pada suhu & + & + & + & + & + & + \\
40ㄷ & & & & & & \\
Pertumbuhan di 3\% NaCl & + & + & + & + & + & + \\
Dihidrolisis arginin & - & + & - & - & - & + \\
Hidrolisi gelatin & - & + & - & - & + & + \\
Hidrolisis pati & - & - & - & - & - & - \\
Uji Hipersensitif & + & + & + & + & + & + \\
\hline
\end{tabular}
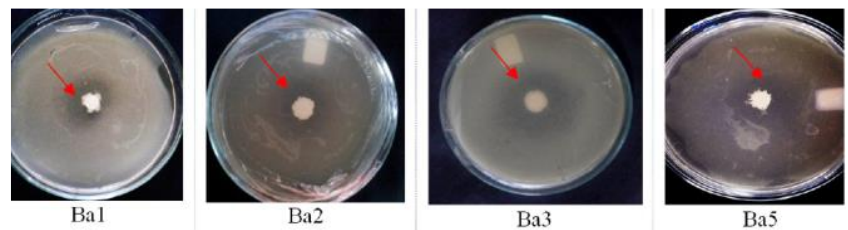

Gambar 8. Zona bening merupakan zona hambat Bacillus spp. terhadap B. glumae. Keterangan: Gambar yang diikuti tanda panah menunjukkan zona bening yang muncul di sekitar isolat Bacillus spp.

Isolat Bacillus spp. perlakuan Ba-5 berbeda sangat nyata mampu menghambat $B$. glumae dibandingkan dengan perlakuan $\mathrm{Ba}-3$ dan $\mathrm{Ba}-4$. Rata-Rata hasil uji daya hambat terendah terdapat pada perlakuan $\mathrm{Ba}-4$ dengan nilai sebesar $0,00 \mathrm{~mm}$ (tanpa hambatan) sedangkan daya hambat tertinggi ada pada Ba-5 dengan nilai sebesar 32,13 mm diikuti perlakuan Ba-1 sebesar 17,88 mm; Ba-2 sebesar 15,88 mm; dan Ba-3 sebesar 9,13 mm (Gambar 9).

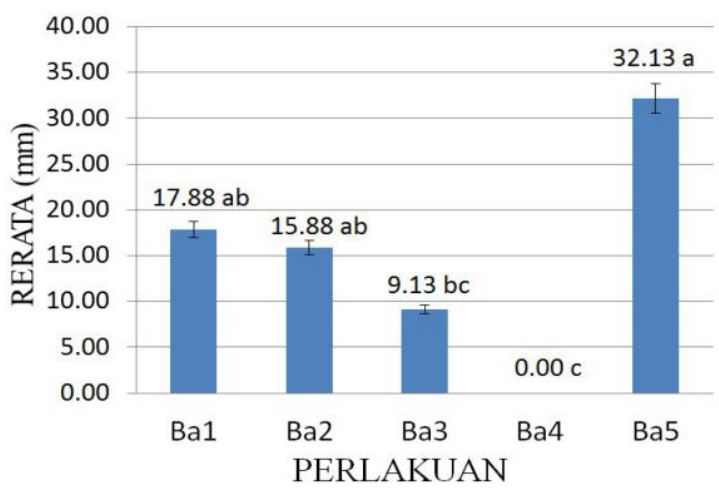

Gambar 9. Rata-rata daya hambat (mm) Bacillus spp. terhadap B. glumae secara in vitro. Angka yang diikuti oleh huruf yang sama menunjukkan berbeda tidak nyata pada taraf DMRT 5\%.

Hasil menunjukkan bahwa mekanisme bakterisidal terjadi pada semua perlakuan kecuali Ba1U2, Ba1U3, dan Ba1U4 yaitu secara bakteriostatik. Mekanisme bakteriostatik ditunjukkan dengan media menjadi keruh setelah 5 hari inkubasi sedangkan bakterisidal menjadi bening (Gambar 10).

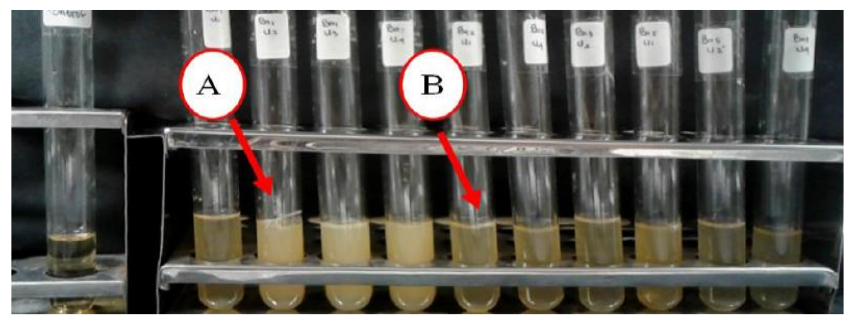

Gambar 10. Hasil pengujian mekanisme penghambatan Bacillus spp. terhadap B. glumae selama 5 hari penggojokan (Kontrol, Ba1U1, Ba1U2, Ba1U3, Ba1U4, Ba2U1, Ba2U4, Ba3U2, Ba5U1, Ba5U2, dan Ba5U4 (dari kiri ke kanan)). Tanda panah menunjukkan hasil reaksi pengujian mekanisme penghambatan (A) Bakteriostatik dan (B) Bakterisidal.

\section{Pembahasan}

Penyakit busuk bulir pada tanaman padi akan menunjukkan gejala penyakit berupa bercak bewarna merah kecoklatan yang menyebar tidak rata pada permukaan bulir padi (Gambar 2). Hal tersebut sesuai dengan deskripsi menurut Magbanua et al. (2014), bahwa tanaman padi yang terserang oleh $B$. glumae akan menunjukkan gejala busuk bewarna merah kecoklatan yang di mulai dari pangkal bulir.

Penyebab perubahan warna bulir padi menjadi merah kecoklatan diduga karena mekanisme infeksi yang terjadi oleh bakteri patogen B. glumae. Berdasarkan hasil penelitian, karakteristik morfologi koloni bakteri B. glumae jika ditumbuhkan pada media SPG (Sucrose Phospate Glutamate) berbentuk bulat dengan warna kuning bening dibagian tepi dan warna ungu tidak tembus pandang di bagian tengah koloni (Gambar 2A). Menurut Nandakumar et al. (2009), isolat B. glumae yang ditumbuhkan pada media SPG memiliki karakteristik koloni bulat konveks, lembut dan memiliki tipe bewarna ungu di tengah koloninya.

Isolat yang ditumbuhkan pada media Kings B memiliki ciri koloni bewarna kuning kehijauan terang (Gambar 3C), berbentuk bulat konveks dengan elevasi cembung yang berukuran 868,70 $\mu \mathrm{m}$ (Gambar 3C dan D) dan tidak berpendar jika dilihat pada sinar UV $(\lambda=$ $366 \mathrm{~nm}$ ) (Gambar 4A) sesuai dengan yang dikemukakan oleh Zhu et al. (2008) bahwa isolat B. glumae yang ditumbuhkan di media Kings B tidak muncul pigmen difusi hijau yang berpendar di bawah sinar ultraviolet.

Pada uji pewarnaan Gram, didapatkan karakteristik morfologi $B$. glumae yaitu sel bakteri berbentuk batang (basil) dengan panjang sel sekitar 2,14 $\mu \mathrm{m}$ dan lebar sel sekitar 0,63 $\mu \mathrm{m}$ (Gambar 4B). Hal tersebut sesuai dengan karakter bakteri $B$. glumae yang dijelaskan oleh Zhu et al. (2008), bahwa B. glumae termasuk basil dengan panjang dan lebar sel berkisar antara 1,5-2,5 $\mu \mathrm{m} \times 0,5-0,7 \mu \mathrm{m}$. Pengujian secara 
fisiologis bertujuan untuk memastikan spesies target sesuai dengan kunci determinasi. Berdasarkan hasil uji Gram dengan $\mathrm{KOH} 3 \%$, isolat B. glumae menghasilkan konsistensi berlendir (reaksi positif) yang artinya termasuk bakteri Gram negatif (Gambar 4C). Menurut Suslow et al. (1982), bakteri Gram negatif memiliki dinding sel yang tipis sehingga mudah pecah pada larutan basa yang tinggi. Pecahnya sel akan mengeluarkan molekul DNA yang bersifat sticky strings. Pengujian oksidatif-fermentatif diinkubasi selama 48 jam dan menunjukan reaksi bersifat oksidatif yang ditunjukkan dengan perubahan warna media dari biru menjadi kuning pada media yang tidak diberi paraffin (Gambar 3D). Hal ini menandakan bahwa $B$. glumae memiliki sistem respirasi aerobik seperti yang dikemukakan oleh Singh dan Vishunavat (2015), bahwa karakter B. glumae bersifat aerobik.

Selanjutnya, uji pertumbuhan pada media YDC (Yeast-Extract Dextrose CaCO3) dan D1M (Media D1). Isolat B. glumae yang ditumbuhkan pada media YDC bereaksi negatif yang ditunjukkan dengan koloni bewarna putih dan tidak mucoid sedangkan pada D1M bereaksi V (antara 21-79\% strain positif) yang ditunjukkan dengan koloni kering serta pertumbuhan lambat selama 5 hari inkubasi. Mikroba memiliki syarat tumbuh pada kondisi $\mathrm{pH}$ beragam yang dikelompokkan ke dalam $\mathrm{pH}$ minimum, optimum, dan maksimum. Hasil pengujian menunjukkan bahwa B. glumae tidak dapat tumbuh pada $\mathrm{pH} 4$ dan dapat tumbuh pada pH 8 (Tabel 1; Gambar 5A, B). Hal ini menunjukkan bahwa $B$. glumae tidak dapat tumbuh kondisi $\mathrm{pH}$ yang asam sehingga $\mathrm{pH} 4$ diartikan sebagai $\mathrm{pH}$ minimum.

Tidak tumbuhnya bakteri pada $\mathrm{pH} 4$ diduga karena perbedaan kondisi $\mathrm{pH}$ di luar sel bakteri dan di dalam sel bakteri sehingga aktivitas enzim tidak bekerja dengan baik. Hal ini disimpulkan bahwa B. glumae bersidat mikroba mesofil (neutrophil) dimana artinya kelompok mikroba yang dapat tumbuh pada kisaran pH 5,5-8,0 (Brooks 1994).

Pertumbuhan pada suhu $40^{\circ} \mathrm{C}$ dilakukan untuk mengetahui reaksi kimia yang berpengaruh dalam laju pertumbuhan bakteri di suhu tertentu. Hasil pengujian B. glumae menunjukkan reaksi positif ditandai dengan adanya perubahan media dari bening menjadi keruh (Tabel 1; Gambar 5C). Hal ini mengartikan bahwa $B$. glumae tergolong bakteri mesofilik dimana jika terjadi peningkatan suhu maka akan mempengaruhi peningkatan atau pertumbuhan bakteri bahkan sampai bakteri tidak dapat tumbuh lagi (Suharni 2008).

Pengujian pertumbuhan pada media LB (Lactose Broth) dengan penambahan $3 \% \mathrm{NaCl}$ bereaksi positif (Tabel 1). Perubahan media menjadi keruh menunjukkan adanya aktivitas bakteri pada media (Gambar 5D). Hal ini diartikan bahwa bakteri dapat mempertahankan keseimbangan tekanan osmotik bakteri atau bersifat isotonik yang artinya bahwa B. glumae mampu menyerap nutrisi di luar sel dengan kondisi kosentrasi zat terlarut pada media seimbang dengan kosentrasi zat terlarut dalam sel bakteri B. glumae (Arisandi et al.
2017). Uji arginin bereaksi positif (Tabel 1; Gambar 6A) dimana media berubah dari pink terang menjadi pink gelap etelah 5 hari inokulasi. Hal tersebut menunjukkan respon $B$. glumae terhadap pemanfaatan arginin dalam kondisi anaerob. Hal ini menunjukkan bahwa bakteri B. glumae dapat memanfaatkan asam amino yang terdapat pada arginin dalam kondisi anaerob.

Hasil pengujian hidrolisis gelatin bereaksi positif yang ditunjukkan dengan pencairan pada media meskipun telah dimasukkan kulkas suhu $-20^{\circ} \mathrm{C}$ (Tabel 1; Gambar 6B). Bakteri B. glumae menghasilkan enzim gelatinase yang ampu mengsekresi enzim dari selnya. Enzim ini berfungsi dalam menghidrolisis senyawa gelatin yang dijadikan sebagai sumber nutrisinya. Menurut Lay (1994), gelatin yang terhidrolisis memiliki sifat tidak dapat kembali (irreversible) ke padat meskipun di simpan pada suhu minus (es) sehingga indikator media yang terhidrolisis adalah media tetap cair.

Pengujian pati menunjukkan reaksi negatif dimana warna media berubah biru setelah di genangi iodin (Gambar 6C). Bakteri B. glumae tidak menghasilkan enzim amylase sehingga tidak mampu menghidrolisis pati. Menurut Putri et al. (2017), enzim amylase berperan dalam pemecahan senyawa kompleks seperti pati (polisakarida) menjadi glukose atau maltose melalui hidrolisa. Aktivitas enzim tersebut dapat dideteksi melalui larutan iodin. Iodine yang tidak berubah warna mengartikan bahwa kandungan pati termanfaatkan oleh isolat bakteri yang begitu pula sebaliknya.

Berdasarkan hasil pengujian daya hambat isolate Bacillus spp. terhadap B. glumae menunjukkan bahwa Bacillus spp. dapat menghambat B. glumae. Hal ini ditunjukkan dengan adanya zona hambat berupa terbentuknya zona bening pada $\mathrm{Ba} 1, \mathrm{Ba} 2, \mathrm{Ba} 3$, dan $\mathrm{Ba} 5$ kecuali pada $\mathrm{Ba} 4$ yang tidak terbentuk zona bening (Gambar 8). Zona bening dapat terbentuk karena Bacillus spp. bersifat antibiosis. Antibiosis merupakan mekanisme bakteri antagonis yang menghasilkan metabolit sekunder berupa antibiotik dan ditunjukkan dengan terbentuknya zona hambatan pada medium berlapis dengan bakteri patogen (Haggag dan Mohamed 2007). Kemampuan Bacillus spp. dalam menghasilkan antibiotik menyebabkan terhambatnya pertumbuhan patogen karena terjadinya difusi antara senyawa antibiotik terhadap media tumbuh (Ernawati 2003). Perlakuan Ba4 tidak menghasilkan daya hambat dimana dapat dipengaruhi oleh gagalnya produksi antibiotik pada kondisi yang tidak menguntungkan (pemberian klorofom). Hal ini diduga disebabkan oleh adanya inhibitor dalam produksi senyawa antibiotik. Berdasarkan Gambar 9, perlakuan Ba5 berbeda sangat nyata dengan perlakuan $\mathrm{Ba} 3$ dan $\mathrm{Ba} 4$ serta $\mathrm{Ba} 5$ berbeda tidak nyata terhadap Ba1 dan ba2. Hal tersebut dipengaruhi oleh daya hambat yang terbentuk pada setiap perlakuan. Menurut Dali et al. (2011), yang menerangkan bahwa besar kecilnya zona hambat dapat 
dipengaruhi oleh beberapa faktor seperti kerapatan koloni dan aktivitas metabolik mikroorganisme.

Berdasarkan hasil uji mekanisme hambatan pada Gambar 9. menggunakan larutan pepton 1\% dan agar dari zona hambat, didapatkan mekanisme penghambatan yang konstan pada perlakuan $\mathrm{Ba} 2$, Ba3, dan Ba5 yaitu secara bakteriosidal. Perlakuan Ba1 tidak konstan dimana pada ulangan Ba1U2, Ba1U3, dan Ba1U4 mengalami mekanisme hambatan secara bakteriostatik. Mekanisme bakteriosidal ditunjukkan dengan perubahan media menjadi bening pada hari ke1 hingga hari ke-5 inkubasi sedangkan mekanisme bakteriostatik ditunjukkan dengan media yang tetap keruh. Menurut Rakasiwi et al. (2016), kemampuan bakteri dalam menghasilkan senyawa antibakteri berbeda yang dipengaruhi oleh massa pertumbuhan bakteri di media. Selain itu, menurut Dwicahyanti et al. (2018), aktivitas senyawa antibiotik bersifat bakteriostatik dapat berubah menjadi bakteriosidal apabila kandungan senyawa antibiotic yang dihasilkan dalam jumlah yang tinggi.

\section{Pernyataan tidak ada konfik kepentingan}

Semua penulis artikel ini menyatakaan bahwa tidak ada konflik kepentingan terkait penelitian dan hasil penelitian ini.

\section{DAFTAR PUSTAKA}

Arisandi A, Wadani MK, Badami K, Araninda GD. 2017. Dampak perbedaan salinitas terhadap viabilitas bakteri Vibrio fluvialis. Jurnal Ilmiah Perikanan dan Kelautan 9 (20): 9197. DOI: 10.20473/jipk.v9i2.7636.

Arwiyanto T. 1997. Pengendalian hayati penyakit layu bakteri tembakau. Perlindungan Tanaman Indonesia 5 (1): 54-60. DOI: $10.22146 /$ jpti.9967.

Brooks. 1994, Mikrobiologi Kedokteran Edisi 2. Indonesia: Penerbit Buku Kedokteran Egc.

Dali S, Usman NH, Ahmad A. 2011. Bioaktivitas antibakteri fraksi protein alga merah Gelidium amansii dari perairan Cikoang Kabupaten Takalar, Sulawesi Selatan. Majalah Farmasi dan Farmakologi 15 (1): 47-52.

Dwicahyanti T, Sumardianto, Rianingsih L. 2018. Uji bioaktivitas ekstrak teripang keling Holothuria atra sebagai antibakteri Staphylococcus aureus dan Escherichia coli. Jurnal Pengolahan dan Bioteknologi Hasil Perikanan 7 (1): 15-24.

Ernawati LMN. 2003. Potensi Mikroorganisme Tanah Antagonis Untuk Menekan Pseudomonas solanacearum Pada Tanaman Pisan Secara In Vitro Di Pulau Lombok. Indonesia: Institut Pertanian Bogor.

Haggag W, Mohamed H. 2007. Biotechnological aspects of microorganism used in plant biological control. World Journal Agricultural Science 3 (6): 771-776.

Izza JF, Aini LQ, Kusuma RR. 2018. Pemanfaatan rhizobakteri dari gulma di UB Forest sebagai agen antagonis penyakit layu bakteri pada kentang. Biotropika 6(2): 54-62.

Kementerian Pertanian RI. 2014. Pusat Data dan Sistem Informasi Pertanian: Impor Komoditi Pertanian Subsektor Tanaman Pangan (Segar). [Online]. www.pertanian.go.id.
Lay BW. 1994. Analisis Mikroba di Laboratorium. Indonesia: PT Grafindo Persada.

Lu W, Pan Zhao PLH, Jia Y, Wang Y, Yu X, Wang X. 2014 Molecular detection of Xanthomonas oryzae pv. oryzae, Xanthomonas oryzae pv. oryzicola, and Burkholderia glumae in infected rice seeds and leaves. The Crop Journal 2(1): 398406. DOI: 10.1016/j.cj.2014.06.005.

Magbanua ZV, Il Buza TMA, Hsu C, Showmaker KC, Chouvarine P, Deng P, Peterson DG, Lu S. 2014. Transcriptomic dissection of the rice Burkholderia glumae interaction. Biomedcentral 15 (755): 1-13. DOI: $10.1186 / 1471-2164-15$ 755 .

Nandakumar R, Shahjahan AKM, Yuan XL, Dickstein ER, Groth DE, Clark CA, Cartwright RD, Rush MC. 2009. Burkholderia glumae and B. gladioli cause bacterial panicle blight in rice in the Southern Inited States. Plant Disease 93 (9): 896-905. DOI: 10.1094/PDIS-93-9-0896.

Prihatiningsih N, Arwiyanto T, Hadisutrisno B, dan Widada J. 2015. Mekanisme antibiosis Bacillus subtilis B315 untuk pengendalian penyakit layu bakteri kentang. HPT Tropika 15 (1): 64-71. DOI: $10.23960 /$ j.hptt.11564-71.

Putra C, Giyanto. 2014. Kompatibilitas Bacillus spp. dan aktinomiset sebagai agens hayati Xanthomonas oryzae pv. oryzae dan pemacu pertumbuhan padi. Fitopatologi 1 (5): 160169. DOI: $10.14692 /$ jfi.10.5.160.

Putri EH, Yuliani L, Lisdiana. 2017. Identifikasi isolat bakteri endofit A1 dan B1 dari akar tanaman ubi jalar (Ipomoea batatas) var. Papua Patippi berdasarkan karakter fenotipik. Lenterabio 6 (3): 62-69.

Rakasiwi V, Bodhi W, Kepel BJ. 2016. Uji resistensi Bacillus yang diisolasi dari plak gigi terhadap merkuri dan gentamisin. Biomedik 4 (1): 6-10. DOI: 10.35790/ebm.4.1.2016.10815.

Saputra R, Arwiyanto T, Wibowo A. 2015. Uji aktivitas antagonistik beberapa isolat Bacillus spp. terhadap penyakit layu bakteri (Ralstonia solanacearum) pada beberapa varietas tomat dan identifikasinya. [Prosiding]. Seminas Nasional Masyarakat Biodiversitas Indonesia. Indonesia.

Schaad NW, Jones JB, Chun W. 2001. Laboratory Guide for Identification of Plant Pathogenic Bacteria, $3^{\text {rd }}$. Amerika: The American Phytopathological Society Press.

Singh D, Vishunavat K. 2015. Identification of a seed-borne rice bacterium, Burkholderia glumae using cultural, morphological and biochemical methods. Applied and Natural Science 7(2): 562-566. DOI: 10.31018/jans.v7i2.645.

Suharni TT, Nastiti, Soetarto ES. 2008. Mikrobiologi Umum. Indonesia: Universitas Atma Jaya.

Suslow TV, Schroth MN, Isaka M. 1982. Application af a rapid method for gram differentiation of plant pathogenic and saprophytic bacteria without staining. Journal of Phytopathology 72(1): 917-918. DOI: 10.1094/Phyto-72-917.

Zhu B, Lou M, Huai Y, Xie G, Luo J, Xu L. 2008. Isolation and identification of Burkholderia glumae from symptomless rice seeds. Rice Science 15(2): 2-5. DOI: 10.1016/S16726308(08)60033-5. 